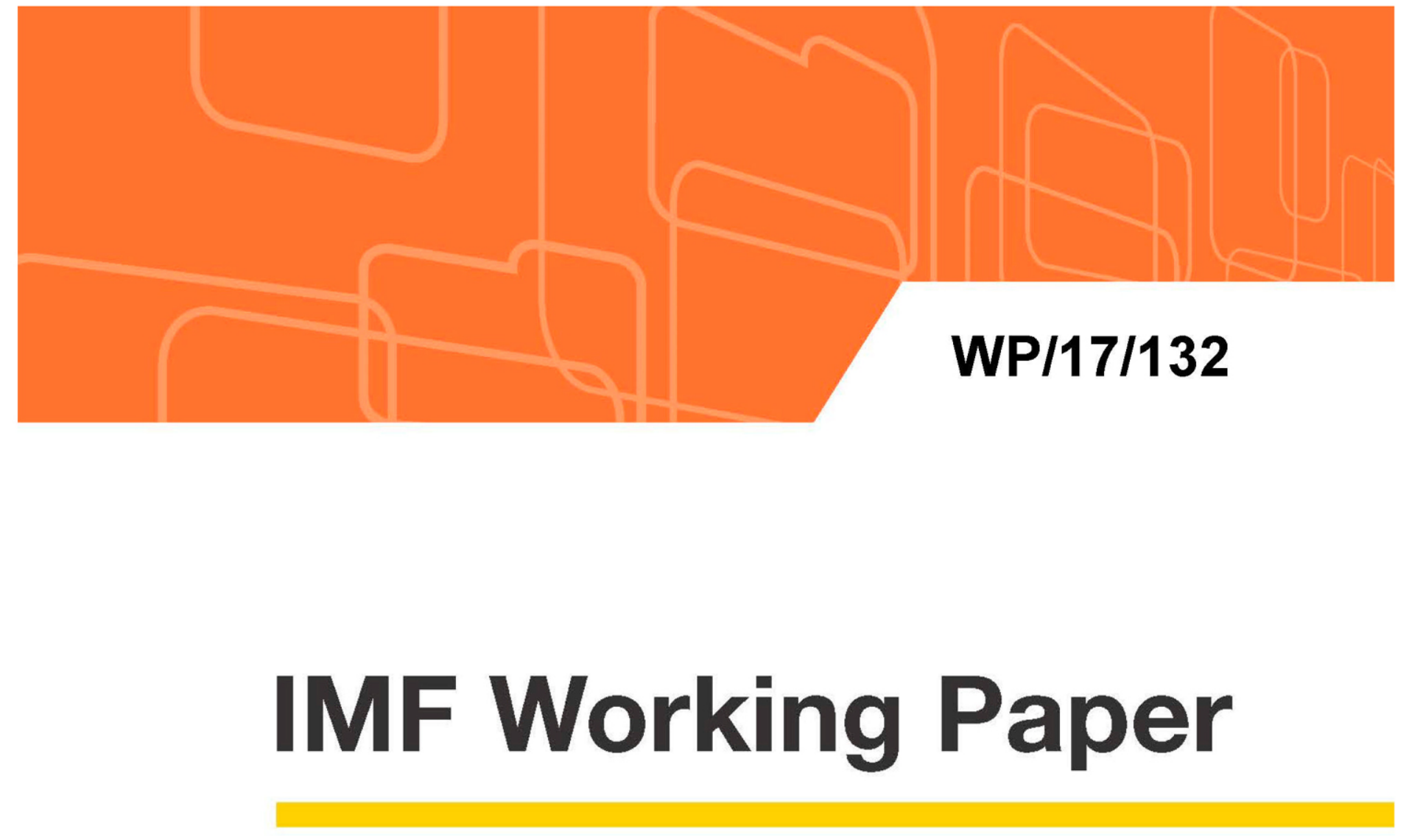

\title{
Deposit Insurance, Remittances, and Dollarization: Survey-Based Evidence from a Top Remittance-Receiving Country
}

by David A. Grigorian and Maxym Kryshko 


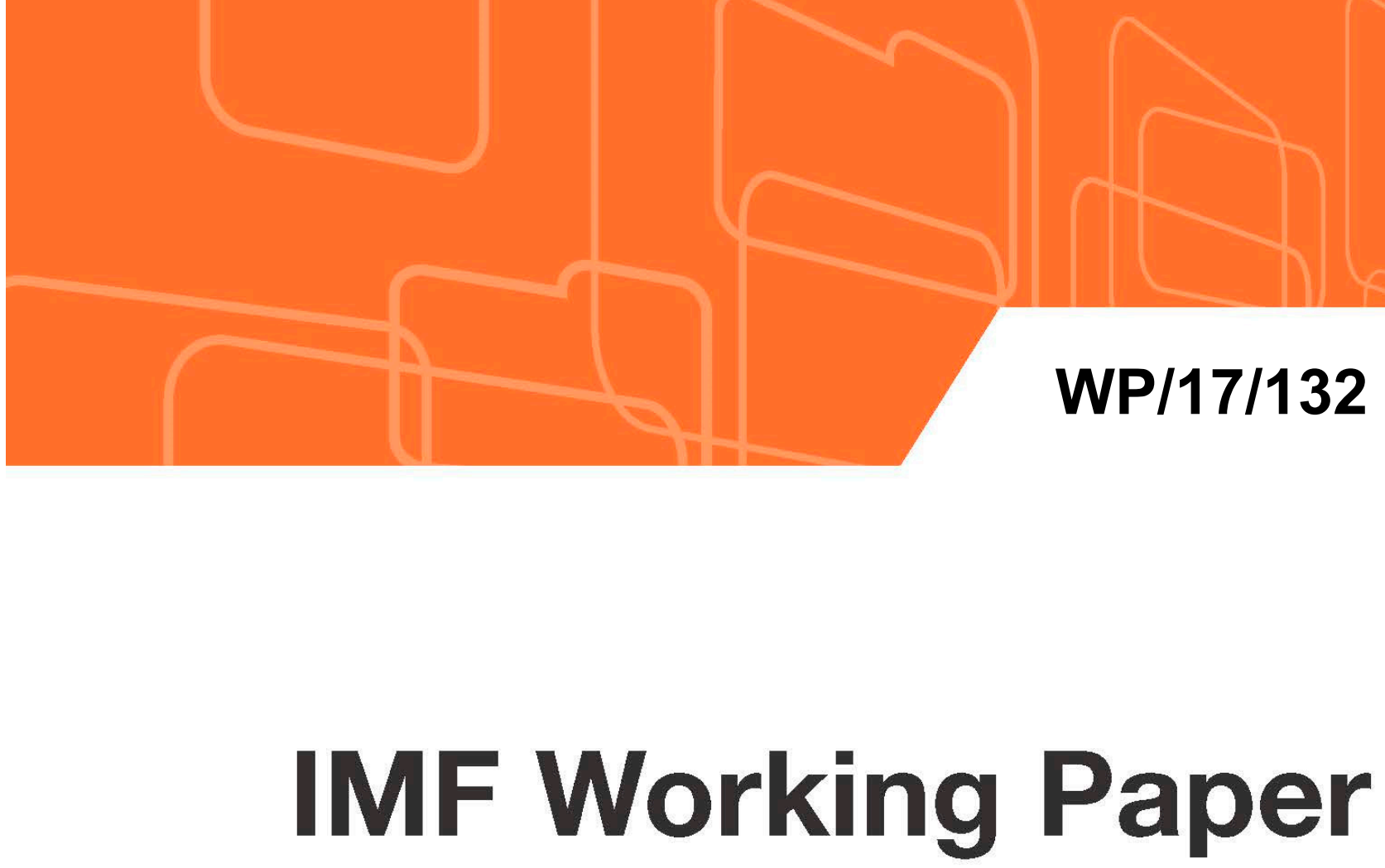

Deposit Insurance, Remittances, and Dollarization: Survey-Based Evidence from a Top Remittance-Receiving Country

by David A. Grigorian and Maxym Kryshko 


\title{
IMF Working Paper
}

Asia and Pacific Department

\section{Deposit Insurance, Remittances, and Dollarization: Survey-Based Evidence from a Top Remittance-Receiving Country}

Prepared by David A. Grigorian and Maxym Kryshko ${ }^{1}$

Authorized for distribution by Daisaku Kihara

June 2017

IMF Working Papers describe research in progress by the author(s) and are published to elicit comments and to encourage debate. The views expressed in IMF Working Papers are those of the author(s) and do not necessarily represent the views of the IMF, its Executive Board, or IMF management.

\begin{abstract}
The paper uses a unique survey of remittance-receiving individuals from Tajikistan to study the impact of policy awareness on consumer behavior. The results show that knowledge of deposit insurance encourages the use of formal channels for transmitting remittances and reduces dollarization. Given the size and importance of remittances in Tajikistan, improving financial literacy and better publicizing details of the social safety net may encourage a more frequent use of formal channels for transferring remittances and reduce reliance on foreign exchange for transaction purposes. This is likely to improve bank profitability, enhance financial stability, and improve access to finance.
\end{abstract}

JEL Classification Numbers: O17 and G28

Keywords: Deposit insurance, remittances, dollarization, Tajikistan

Author's E-Mail Address: dgrigorian@,imf.org and mkryshko@,imf.org

\footnotetext{
${ }^{1}$ The authors would like to thank Odd Per Brekk, Carolina Castellanos, Cevdet Denizer, Giuseppe Iarossi, and Yuri Sobolev for helpful comments. The remaining errors are their own.
} 


\section{INTRODUCTION AND MOTIVATION}

A well-functioning deposit insurance (DI) scheme could be an important deterrent for a bank run and a subsequent financial crisis in both developed and developing countries. In a developing country set-up, it may also play an important role in determining whether individuals trust the financial sector enough to transact with it. In addition, lack of trust could influence the currency mix of savings and cash balances, often posing a considerable challenge for the conduct of the monetary policy and making a financial crisis more likely. ${ }^{2}$ Thus, DI could have implications for both development as well as stability aspects of functioning of a financial system.

The 2008 global financial crisis and its aftermath in Europe tested the trustworthiness and reliability of DI schemes. Banking sectors of some (core and non-core) EU countries experienced massive deposit outflows despite fairly generous deposit protection schemes in place (Grigorian and Manole, 2016). And while arguably no DI scheme is designed to provide guarantee against a systemic crisis, in some cases DI schemes were not seen as sufficiently credible to help avoid even individual bank runs (e.g., the case of Northern Rock in UK in 2007). As we will see in Section II, lack of awareness of DI may be behind some of these outcomes.

Practitioners have long emphasized the importance of public's knowledge about DI. As stated by IADI (2009), "public awareness of deposit insurance - its existence and how it works - plays a significant role in underpinning a sound deposit insurance system." In fact, public awareness is one of the Core Principles for Effective Deposit Insurance Systems (BIS, 2009). So (adequate) knowledge of DI schemes could be an important factor for maintaining financial stability and preventing crises.

Financial illiteracy in general and lack of awareness of DI in particular may prevent households from more frequent use of formal (financial) sector and contribute to dollarization. This could pose policy challenges for small open economies with fragile financial sectors that face significant financial flows. The paper uses one such example, Tajikistan - a small open economy that receives in excess of 40 percent of GDP in remittances - to study these relationships.

To the best of our knowledge this is the first paper that looks at the impact of DI awareness - an element of financial literacy — on the method of transfer and the use of remittances. The paper argues that educating consumers about DI can help channel a larger share of remittances through the formal channels and reduce the dollarization of their use. The main hypotheses to be tested in the paper are as follows:

Hypothesis 1: Knowledge of DI is important for channeling the remittances through the formal financial sector.

Hypothesis 2: Knowledge of DI reduces cash dollarization and encourages more saving and borrowing in domestic currency.

\footnotetext{
${ }^{2}$ Remittances that are channeled outside of the banking system provide more fertile ground for money laundering than those channeled through the banking system (e.g., Kireyev, 2006).
} 
The paper is structured in the following way. Section II surveys the literature and discusses the empirical findings on the role of awareness of DI on the way the remittances are channeled and on the dollarization of their use. Section III discusses the specifics of Tajikistan, the country case used in the study, and the underlying data. Section IV outlines the empirical strategy and summarizes the main findings. Section V concludes.

\section{LiteratURE SURVEY}

It has been established that remittances - especially if channeled through the format financial system - promote financial development. Using data on remittance flows to 109 developing countries during 1975-2007, Aggarwal, Demirgüç-Kunt, and Martínez Pería (2011) study the link between remittances and financial sector development. In particular, they examine the association between remittances and the aggregate level of deposits and credit intermediated by the local banking sector. The study provides evidence of a robust link between remittances and financial development in developing countries. ${ }^{3}$

\section{Deposit insurance vs. methods of remitting}

While informal methods of transferring remittances might be popular among migrant workers in some countries, as conjectured above, the use of formal methods enhances the development potential of remittances. The resulting increased transparency and accountability in the remittance market positively affects not only the government and the financial sector, but also the individual remitters and their families (e.g., Hernandez-Coss, 2005). Suki (2004) notes that improving the intermediation of remittances can increase savings mobilization and relieve credit constraints for low income groups.

The choice between using formal and informal channels of remitting funds can be influenced by a number of factors. As expected, cost of transfer and the remitter's legal status in the host country have been found to be important factors influencing that choice (see, for example, Siegel and Lücke, 2009). In addition, laws and regulations as well as infrastructure development in the home country may provide implicit insurance for remitters to use the formal system by improving the functioning of the overall financial sector. A study of the Philippines, Abenoja (2004), argues for an appropriate regulatory environment and financial infrastructure (such as, payment systems for low-value payments) help bring more of remittance flows into the formal sector. Hernandez-Coss (2005) calls for facilitation of the entry of nonbank financial institutions (e.g., credit unions and microcredit institutions) into the workers' remittance market in Dominican Republic, thus stressing the role of competition among financial institutions.

There is also a more explicit way of making the relationship between the remitters (and depositors in general) and the formal financial system safer and more attractive. One way to achieve this would be to put in place a DI scheme that guarantees most, if not all, deposits of

\footnotetext{
${ }^{3}$ However, as Grigorian and Melkonyan (2011) show, at the household level remittances do not necessarily translate into stronger relations with the banking sector.
}

(continued...) 
typical remittance-receiving households. ${ }^{4}$ This may encourage remitters to set up bank accounts in their home countries and use them for remittance transfer purposes. However, no research to date has looked at the role/impact of DI on the use of formal vs. informal channels for remitting. We attempt to shed some light on this issue in this paper.

\section{Deposit insurance vs. dollarization (of the use of remittances)}

The impact of DI on bank behavior is ambiguous. Anginer, Demirguc-Kunt, and Zhu (2013) show that (generous) financial safety nets could increase the moral hazard and, therefore, increase the risk-taking by banks and reduce systemic stability in non-crisis years. However, the authors find that bank risk is lower and systemic stability is greater during the global financial crisis in countries with DI coverage. Similarly, Inter-American Development Bank (2004) shows that the moral hazard resulting from DI could lead to higher level of financial dollarization, as banks take more risk, including FX-related. Using a sample of 14 Latin American countries between 1995 and 2001, Barajas and Morales (2003) find that the coverage ratio of DI scheme (defined as the maximum coverage divided by per capita income) is significantly and positively associated with a higher level of dollarization in bank lending. Contrary to these findings, however, a study by Luca and Petrova (2003) of 23 transition countries finds that the presence of explicit DI is not significantly associated with a higher level of credit dollarization. ${ }^{5}$

In contrast, the impact of DI on depositor behavior is more predictable (less ambiguous): presence of an explicit insurance scheme in a country is likely to boost depositor confidence and increase deposits ceteris paribus. However, two factors may have an impact on this relationship, thus potentially influencing the behavior of depositors: (1) if the depositors are aware of the existence of the DI scheme and the benefits it offers and (2) whether the DI protection is considered (by depositors) to be credible/sufficient to safeguard their deposits. In both cases, depositors are likely to adjust their deposits (relative to the optimum) and/or seek additional insurance against potential deposit losses. To the extent that banking crises are accompanied by domestic currency devaluation, holding deposits in foreign currency could provide (partial) insurance against loss. This (perceived inadequacy in DI coverage) will lead to more (deposit) dollarization.

To date, no empirical study has looked at the implications of the awareness of DI on dollarization. However, general financial literacy may be a good proxy for DI awareness. Using survey data from Albania, Narazani (2013) finds that financial literacy appears to be positively related with the preference of urban households to hold Euro both in cash and in the form of deposits. Employing micro-level survey data for ten Eastern European countries, Brown and Stix

\footnotetext{
${ }^{4}$ This may not require any significant extensions of DI coverage in most countries, since remittancereceiving families are likely to be low- or middle-income and therefore have below-average deposit balances.

${ }^{5}$ While the issue of the currency coverage of DI schemes goes outside of the scope of this paper, it is nevertheless interesting to note that, as argued by Billmeier and Mathisen (2006), limiting the coverage of deposit protection to deposits held in domestic currency could indirectly contribute to lowering dollarization and currency mismatches by providing further incentives to hold savings deposits in domestic currency.
} 
(2014) find that the assessment of future monetary conditions (e.g., the expectation of a depreciation within a year, etc.) have a stronger positive impact on preference of holding foreign exchange among more financially literate households than among financially illiterate ones.

\section{Awareness of DI vs. household financial decisions}

However, empirical studies find that awareness of DI is generally not universal and has implications for depositor behavior. Data collected by Bartiloro (2011) in Italy during European sovereign debt crisis show that 70 per cent of the households were completely unaware of the existence of DI scheme, 23 per cent possessed only basic knowledge, and just seven per cent had detailed information about it. Similarly, for Germany, Strater, Cornelissen, and Pfingsten (2008) show that awareness of DI is not universal, affecting individuals' perception of risk and confidence in deposit protection.

As shown by Inakura, Shimizutani, and Paprzycki (2005), in Japan too DI awareness has not been universal. Using a detailed household data, the study shows that in 1996 just over half of households knew of the DI scheme and only seven percent of households knew the detailed contents of the scheme. ${ }^{6}$ The authors show that the degree of awareness was an important determinant of households' decisions to switch banks in response to risks.

For the Netherlands, Bijlsma and van der Wiel ((2012 find that knowledge of DI is limited, particularly when it concerns depositors in small banks. Nevertheless, households with more deposits have better knowledge of DI scheme and show higher levels of trust. In addition, deposit holders generally expect an associated payback time that well exceeds the time it has taken to pay back depositors in the past. Moreover, consumers believe repayment is more likely and faster for large, systemic banks. These results confirm that both households' awareness of the coverage and trust in the operations of DI scheme are suboptimal.

Consistent with the above results, Lusardi (2008) shows that financial illiteracy in general is widespread among the U.S. population and is particularly acute among specific demographic groups (e.g., households with low levels of education, women, African-Americans and Hispanics, etc.) and that low literacy and lack of information affect the ability to save.

\section{BACKGROUND AND DATA}

\section{A. Background}

\section{A unique case study}

Remittances play an important role in Tajikistan. In 2014, the economy received an estimated $\$ 4$ billion in remittances, equivalent to 42 percent of GDP, the largest share among all remittance-receiving countries in the world. A lion share of remittances (up to 90 percent in

\footnotetext{
${ }^{6}$ The situation has improved over time. The 2001 survey shows that a quarter of households had detailed knowledge of the reintroduction of the deposit insurance cap, its timing and the types of deposits concerned, while about 70 percent knew at least some details.
} 
volume) are received from Russia, followed by Kazakhstan and Belarus. ${ }^{7}$ However, perhaps contrary to the common belief, the 2014 Russian crisis demonstrated that remittances are not robust and can fluctuate significantly: in 2015, remittances from Russia declined by an estimated 25 percent year-on-year, significantly complicating the macroeconomic policy conduct in Tajikistan.

According to the World Bank's Remittance Prices Worldwide (RPW) database, the cost of sending the equivalent of $\$ 200$ from Russia to Tajikistan is on average 2.2 percent (as of 2014) as compared to a global average of 8 percent. Competition among local money transfer operators (MTOs) is likely to have contributed significantly to the cost of remitting. In addition, (relatively minor) improvements in banking services, reduction of costs of money wiring, and assurances of unrestricted withdrawals of transfers were sufficient to change the attitude of households to use of banking from one of hostility to acceptance (Kireyev, 2006).

Despite the significant remittance flows (some of which are channeled through the formal channels, the financial sector; see below), Tajikistan has one of the lowest levels of financial inclusion in Europe and Central Asia. According to Global Financial Inclusion Database 2011 (Global Findex) only 2.5 percent of adult population over 15 had an account at formal financial institution, 0.3 percent saved, and only 5 percent had a loan. Informally, 14 percent of adults saved and 31 percent reported having a loan, which primarily originated from family or friends. Finally, at the time the survey was conducted (see Section III.B), Internet and mobile banking were incipient and the legal framework for mobile banking services was under development.

\section{Remittances and the financial sector}

An estimated two thirds of total remittances is channeled through commercial banks (and to a lesser extent some large microcredit deposit organizations, MDOs), each serving as agent of several (local and international) MTOs. ${ }^{8}$ Anecdotally, this constitutes a significant source of noninterest earnings for the banks that are active in the remittance market. ${ }^{9}$ In addition, as a significant source of income for households, remittances in Tajikistan are also important for the ability to repay bank loans. Finally, remittances are an important source of liquidity for the banks. ${ }^{10}$ Given their role and significance, understanding the factors that encourage households to channel their remittances via the banking sector is important and can have significant stability implications for an otherwise fragile banking sector.

\footnotetext{
${ }^{7}$ Kireyev (2006) discusses the difficulties of measuring remittance flows in Tajikistan.

${ }^{8}$ Under the Law "On Banks and Banking Activities" the NBT grants banks a license to provide financial services, including international remittance transfers. MTOs are neither licensed nor supervised by the NBT, and can only operate through banks (or large MDOs).

${ }^{9}$ Unfortunately, the banks' income statement data are not granular enough to calculate the share of remittance-related fees.

${ }^{10}$ Although funds are available for withdrawal almost immediately after they are deposited by the remitter, they are typically not claimed right away. One of the reasons is geographic isolation of some areas, making travel to a bank branch difficult/costly/infrequent. Anecdotally, one of the largest banks was able to stay afloat during 2014-15 due largely to remittance-related liquidity.
} 
Notwithstanding the prominent role played by the banks in remittance transfers to Tajikistan, the funds are predominantly disbursed in cash, do not stay in the banking sector, and are mostly kept in foreign exchange. Account/payment card services are hardly available to remittance recipients, who are unbanked to a large extent. Based on a sample used in this paper (see below). over 70 percent of recipients do not wish to deposit remittance funds into a bank account, in part due to immediate consumption necessities and over 80 percent of recipients prefer to receive the funds in foreign currency.

IMF (2016) highlights the weaknesses in the banking sector of Tajikistan. The system is small (total assets at around 30 percent of GDP) and is not liquid. While capital buffers are high on paper, they are likely to be overstated due to misclassification and underprovisioning of bad loans. The sector suffers from the legacy of directed lending and nonperforming loans (NPLs) are high, having grown rapidly in recent years, especially in large banks. Overall financial intermediation is low, compared with the Caucasus and Central Asia peer country groupings, with credit-to-GDP ratio remaining below 20 percent.

One way the remittances have made the financial sector in Tajikistan more susceptible to shocks is that they have contributed to the dollarization of the sector. Prior to the global financial crisis, dollarization had been as high as 75 and 79 percent for bank loans and deposits, respectively. Starting 2011, both indicators of dollarization have been on the rise, reflecting a lack of confidence in the domestic currency, somoni (TS), and the risky business environment. The overwhelming majority of private enterprises that borrow in foreign exchange earn income in somoni and are therefore not hedged against potential depreciation.

\section{Safety Net: Deposit Insurance Fund}

Tajikistan's financial sector safety net is in its infancy. The Deposit Insurance Fund (DIF) is a key part of the safety net, established in 2003 as a simple paybox. The coverage level was raised from TS7,000 to TS14,000 in 2015 and TS17,500 in 2017 (approximately \$2,100). ${ }^{11}$ At the time the survey used in this paper was conducted (see below), DIF provided full coverage of approximately 85 percent of depositors' savings in member banks, with the average amount of the insured deposits at approximately $\$ 100$. The coverage has since increased and stood at 96 percent at end-2016.

Apart from one bank (Amonatbank, the savings bank, whose liabilities are fully secured by the state), the remaining 17 banks and 38 micro-credit deposit organizations are mandatory members of DIF. The fund has accumulated assets of over TS260 million ( $\$ 33$ million) fully funded by the industry and reached 6.3 percent of total deposits as of end-2016 (against the target of seven percent). DIF may be making a real loss on its fund investment, due to very low rates on government treasury securities. Deposits in foreign currencies are covered, but the repayment of these deposits is done in local currency only. ${ }^{12}$ In addition to having low coverage level, the local

\footnotetext{
11 The coverage limit was twice per capita GDP at its inception. A recent financial sector assessment conducted by the World Bank and International Monetary Fund (WB-IMF, 2015) recommended an increase of the DI coverage level up to TS20,000.

${ }^{12}$ Since repayments on FX deposits is done in local currency only, the depositors bear some foreign exchange risk.
} 
currency compensation is seen as problematic by market participants in a country with extensive dollarization and foreign currency remittances from abroad. While the DIF has put in place a variety of communication tools (e.g., website, posters, and a handout) to inform the public of its existence, it has not conducted any surveys on the public awareness of the DI scheme.

\section{B. Data}

The survey used in the paper was conducted by the National Bank of Tajikistan in mid-2014 in each of the 24 administrative regions of Tajikistan with a sample of roughly 250 people per region. Individuals, who entered commercial banks' branches to conduct banking or pay for utilities via terminals located in bank branches, were asked to fill out a 2-page questionnaire (see Appendix, translated from Tajik).

Basic statistical indicators for key variables of interest are presented in Table 1 below. The following characteristics of the data are interesting to note: nearly 68 percent of respondents use formal channels for remitting/receiving transfers; over three quarters of respondents are aware of the DI protection offered through the banks; ${ }^{13} 38$ percent of respondents are women; 57 percent reside in villages; 79 percent are married; 48 percent have some kind of post-secondary education; remittance constitute between 10 and 30 percent of the respondents' income; 65 percent of respondents consider themselves employed; and 30 percent of them borrow from the banks. A lion share of transfers indeed comes from Russia (nearly 80 percent), with Kazakhstan a distant second ( 7 percent), followed by Belarus ( 3 percent) and other countries.

Table 1. Descriptive Sample Statistics

\begin{tabular}{lccccrr}
\hline & Mean & Median & Minimum & Maximum & Std. Dev. & Observations \\
\hline REMITTING VIA BANKS & 0.680 & 1 & 0 & 1 & 0.467 & 5,416 \\
DI_AWARE & 0.785 & 1 & 0 & 1 & 0.411 & 5,416 \\
FEMALE & 0.376 & 0 & 0 & 1 & 0.484 & 5,416 \\
VILLAGE & 0.567 & 1 & 0 & 1 & 0.495 & 5,416 \\
TOWN & 0.253 & 0 & 0 & 1 & 0.435 & 5,416 \\
MARRIED & 0.794 & 1 & 0 & 1 & 0.404 & 5,416 \\
EDUCATION_HIGHER_PLUS & 0.485 & 0 & 0 & 1 & 0.500 & 5,416 \\
REMITTANCES-TO-INCOME & 0.198 & 0.150 & 0.100 & 0.300 & 0.075 & 4,535 \\
EMPLOYED & 0.649 & 1 & 0 & 1 & 0.477 & 5,416 \\
BORROW_FROM_BANKS & 0.297 & 0 & 0 & 1 & 0.457 & 5,416 \\
NOTRUST_IN_BANKS & 0.131 & 0 & 0 & 1 & 0.337 & 5,416 \\
REMITTANCES' ORIGIN & & & & & & \\
$\quad$ RUSSIA & 0.79 & 1 & 0 & 1 & 0.462 & 4,702 \\
$\quad$ KAZAKHSTAN & 0.07 & 0 & 0 & 1 & 0.241 & 4,702 \\
$\quad$ BELARUS & 0.03 & 0 & 0 & 1 & 0.170 & 4,702 \\
$\quad$ OTHERS & 0.10 & 0 & 0 & 1 & 0.281 & 4,702 \\
\hline
\end{tabular}

${ }^{13}$ The fact that the sample was collected in bank branches (regardless of what the individuals were doing there) may bias the sample, potentially explaining a high ratio of individuals who were aware of DI. However, this bias does not seem to be important, as we demonstrate below. 
Before we move to the empirical results, a disclaimer is due here. The analysis presented in the paper was conducted based on the data collected prior to the ongoing financial crisis in Tajikistan. While the findings may have contributed to the outcome, the paper does not touch upon the main reasons behind the crisis.

\section{EMPIRICAL RESULTS}

The following four sets of equations aim to explain the factors behind: (1) using the formal/banking sector for channeling remittances, (2) keeping cash exclusively in foreign exchange, (3) keeping deposits exclusively in foreign exchange, and (4) borrowing from a bank exclusively in foreign exchange.

$$
\begin{aligned}
& \text { Remitting via Bank }=F(\text { Awareness of DI; Controls } \mid \text { Rem-Receiving=1) } \\
& \text { Holding Cash in FX }=F(\text { Awareness of DI; Controls } \mid \text { Rem-Receiving=1) } \\
& \text { Holding Deposits in FX } F(\text { Awareness of DI; Controls } \mid \text { Rem-Receiving=1) } \\
& \text { Borrowing in } F X=F(\text { Awareness of DI; Controls } \mid \text { Rem-Receiving=1) }
\end{aligned}
$$

The main policy variable of interest is Awareness of DI, a binary indicator (arguably subject to imperfections and measurement problems), which we expect to play a significant role in all regressions. Equation 1 will be used to test Hypothesis 1, while equations 2-4 will be used for testing Hypotheses 2. Given the nature of the dependent variable, a probit regression model was used for estimating all four regression equations.

\section{A. Deposit Insurance Awareness vs. Channels of Remittance Transfer}

Table 2 contains the results of the regression with probability of using formal channel for transmitting remittances as the dependent variable. The estimated coefficient for the main variable of interest, DI awareness (DI_Aware), has the right sign and is statistically strongly significant. Awareness of DI makes it 28 percent more likely that formal channels for receiving remittances are used.

The regression outcome for control variables offer some interesting insights:

- With age individuals are more likely to use formal channels of remitting, but at a declining rate and not in a statistically significant fashion;

- Female recipients and residents of villages are more likely to use informal channels;

- Married and more educated individuals are more likely to use formal channels;

- Use of formal channels is negatively associated with employment and the receiving individuals' level of income;

- The higher the share of remittances in total income, the more likely for the recipients to use the formal channels. ${ }^{14}$

\footnotetext{
${ }^{14}$ This is consistent with the results of Kose and Vermeulen (2014), who find that the larger payments are more likely to be transferred via formal channels.
} 
Table 2. Probit Regression Results: Use of Formal Channels for Remitting

(Dependent Variable: Probability of Receiving Remittances via Banks)

\begin{tabular}{|c|c|c|c|c|c|c|c|c|}
\hline Variable & Coeff. & $\begin{array}{c}\text { Std. } \\
\text { Error }\end{array}$ & Coeff. & $\begin{array}{c}\text { Std. } \\
\text { Error }\end{array}$ & Coeff. & $\begin{array}{l}\text { Std. } \\
\text { Error }\end{array}$ & Coeff. & $\begin{array}{l}\text { Std. } \\
\text { Error }\end{array}$ \\
\hline $\mathrm{C}$ & -1.03 & 2.46 & -0.72 & 2.47 & -1.04 & 2.46 & -1.27 & 2.52 \\
\hline DI_AWARE & $0.28 * * *$ & 0.06 & $0.27 * * *$ & 0.06 & $0.28 * * *$ & 0.06 & $0.28 * * *$ & 0.06 \\
\hline BORROW FROM BANKS & & & $0.21 * * *$ & 0.06 & & & & \\
\hline DI_AWARE * NOTRUST_IN_BANKS & & & & & -0.03 & 0.09 & & \\
\hline \multicolumn{9}{|l|}{ REMITTANCES' ORIGIN } \\
\hline RUSSIA & & & & & & & $0.79 * * *$ & 0.07 \\
\hline KAZAKHSTAN & & & & & & & 0.07 & 0.10 \\
\hline BELARUS & & & & & & & -0.13 & 0.14 \\
\hline FEMALE & $-0.14 * * *$ & 0.05 & $-0.13 * * *$ & 0.05 & $-0.14 * * *$ & 0.05 & $-0.14 * * *$ & 0.05 \\
\hline LOG(AGE) & 2.1 & 1.35 & 1.89 & 1.36 & 2.11 & 1.35 & 1.81 & 1.39 \\
\hline $\mathrm{LOG}(\mathrm{AGE})^{\wedge} 2$ & $-0.31 *$ & 0.19 & -0.28 & 0.19 & $-0.31 *$ & 0.19 & -0.27 & 0.19 \\
\hline VILLAGE & $-0.26 * * *$ & 0.06 & $-0.26 * * *$ & 0.06 & $-0.26 * * *$ & 0.06 & $-0.24 * * *$ & 0.06 \\
\hline MARRIED & $0.14 * *$ & 0.06 & $0.15 * *$ & 0.06 & $0.14 * *$ & 0.06 & $0.11 *$ & 0.06 \\
\hline EDUCATION_HIGHER_PLUS & $0.18 * * *$ & 0.05 & $0.18 * * *$ & 0.05 & $0.18 * * *$ & 0.05 & $0.18 * * *$ & 0.05 \\
\hline LOG(INCOME) & $-0.19 * * *$ & 0.04 & $-0.19 * * *$ & 0.04 & $-0.19 * * *$ & 0.04 & $-0.18 * * *$ & 0.05 \\
\hline REMITTANCES-TO-INCOME & $1.73 * * *$ & 0.41 & $1.66^{* * *}$ & 0.42 & $1.73 * * *$ & 0.41 & $1.47 * * *$ & 0.42 \\
\hline EMPLOYED & $-0.23 * * *$ & 0.06 & $-0.23 * * *$ & 0.06 & $-0.23 * * *$ & 0.06 & $-0.22 * * *$ & 0.06 \\
\hline REGIONAL DUMMIES (23) & included & & included & & included & & included & \\
\hline McFadden R-squared & 0.24 & & 0.24 & & 0.24 & & 0.27 & \\
\hline S.D. dependent var & 0.42 & & 0.42 & & 0.42 & & 0.42 & \\
\hline Mean dependent var & 0.77 & & 0.77 & & 0.77 & & 0.77 & \\
\hline Log likelihood & $-1,798$ & & $-1,792$ & & $-1,798$ & & $-1,713$ & \\
\hline Obs with Dep $=0$ & 995 & & 995 & & 995 & & 995 & \\
\hline Obs with Dep $=1$ & 3,404 & & 3,404 & & 3,404 & & 3,404 & \\
\hline Total obs & 4,399 & & 4,399 & & 4,399 & & 4,399 & \\
\hline
\end{tabular}

Note: $* * *, * *$, and $*$ represent significance at 99,95 , and 90 percent confidence level, respectively. 
The importance of DI awareness may potentially vary with individuals' trust in the financial sector, as the underlying source of the risk that DI aims to cover. To test for this relationship, we interacted the DI awareness with the response given by the interviewees to the question 12 (Option 1; see Appendix). ${ }^{15}$ The results are reported in Table 2 (third regression). Apparently, the DI awareness matters irrespective of the trust in banks: while the coefficient on the interacted term is negative (suggesting that if there is no trust in banks, the DI awareness matters less), the effect/difference is not statistically significant.

To account for a potential sample bias (see footnote 12), we run the baseline regression using only individuals, whose family members have not borrowed from a bank (based on Question 13; or 70 percent of the main sample per Table 1). ${ }^{16}$ Doing so is likely to make the resulting subsample closer to that of general population, which has limited interactions with the banking system, as described above. The results are qualitatively very similar to those reported in Table 2, with DI_Aware having a somewhat larger coefficient (0.39 vs. 0.28), implying a greater return to awareness of DI when the connection to the banking sector is weak or nonexistent. ${ }^{17}$

Finally, to account for any difference in (direct or indirect) cost of remitting between countries of origin, we used dummy variables for those countries as a proxy (Table 2, fourth regression). Transfers from Russia are very likely to be made using formal channels, perhaps a reflection of low cost and presence of a wide bank branch network in areas (of Russia) where Tajik remitters reside. The coefficients on Kazakhstan and Belarus are statistically

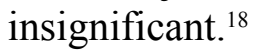

\section{A potential problem with the current model}

DI awareness can potentially be endogenous with respect to the choice of formal vs. informal channels for remitting. We tested for potential endogeneity by using Rivers and Vuong (1988) approach. It requires running an OLS regression of the independent variable (DI aware) on a valid instrument ${ }^{19}$ (and all controls), then adding the residual from that regression to the baseline (probit) model as a regressor. Simple $t$-statistic for the significance of that

\footnotetext{
${ }^{15}$ While an imperfect measure, this is the closest the survey comes to gauging respondents' trust (or lack thereof) in the banking sector. Interestingly, DI awareness is not always associated with trust in banks. In fact, the association is very weak, with in-sample correlation coefficient between NOTRUST_IN_BANKS and DI_Aware being at -0.143.

${ }^{16}$ Unfortunately, the survey did not ask whether individuals had bank accounts, which would have been a better variable to choose while restricting the sample for bias-testing.

${ }^{17}$ The results are not reported but are available from the authors upon request.

${ }^{18} \mathrm{We}$ also tested for any differences in the type of remittance flows (i.e., seasonal work vs. family members or relatives living abroad, etc.). The results (not reported) are inconclusive.

${ }^{19}$ A valid instrument is expected to be correlated with the explanatory variable but have no independent effect on the dependent variable.
} 
regressor will be the test for endogeneity of DI_Aware with respect to the choice of the channel for remitting.

To run the test, we constructed an instrument that takes value of 1 if at least one answer to the Question 9.1 ("What is the reason for depositing your money in forex in the bank?") is checked and 0 otherwise. The rationale is that if a person has a reason to deposit money at the bank, then he most probably visits bank premises to make deposits and is more likely to be aware of DI. In addition, we expect this instrument to have no independent effect on the choice of the channel. The results are encouraging. While the first stage (OLS) regression shows that the instrument has the right sign and is significant, the residual from that equation is not significant when used as a regressor in the second stage (probit) regression. ${ }^{20}$ Therefore, we conclude that DI_Aware is not endogenous in the baseline model.

\section{B. Deposit Insurance Awareness vs. Dollarization}

The remainder of this section tests for the relationship between DI awareness and the use of dollarization proceeds. Table 3 (first regression) contains estimation results with the probability of keeping cash exclusively in foreign exchange as the dependent variable. As conjectured above, DI awareness reduces cash dollarization in a statistically significant fashion.

The coefficient estimates on control variable are interesting. Village residents, people with high income, those employed and receiving higher share of income in remittances are likely to hold cash exclusively in FX. Age, marital status, and higher education do not seem to impact the probability that cash is held exclusively in forex.

As to be expected, motives for holding cash too may have implications for the currency composition. As shown by the second regression results in Table 3, those who use foreign exchange as source of income or to develop foreign trade activities are more likely to hold cash exclusively in FX. Conversely, individuals who cite exchange rate protection or the need to develop domestic trade activities are less likely to hold cash exclusively in FX (and more likely to hold somoni balances as part of their cash buffer).

Finally, we tested whether the preference to pay in specific currency has an impact on how the individuals keep their cash balances. As expected, individuals who prefer to pay in somoni are less likely to keep their cash balances in FX. Conversely, those who prefer to pay in either dollars, euros, or rubles, are very likely to keep their balances in FX. Note that adding the payment preference choices improves the regression fit while leaving the sign and significance of the main variable of interest (DI_Aware) and the control variables unchanged.

${ }^{20}$ The results are not reported but are available from the authors upon request. 
Table 3. Probit Regression Results: Cash Dollarization (Dependent Variable: Probability of Keeping Cash Exclusively in Foreign Exchange)

\begin{tabular}{|c|c|c|c|c|c|c|}
\hline Variable & Coeff. & $\begin{array}{r}\text { Std. } \\
\text { Error } \\
\end{array}$ & Coeff. & $\begin{array}{r}\text { Std. } \\
\text { Error } \\
\end{array}$ & Coeff. & $\begin{array}{r}\text { Std. } \\
\text { Error } \\
\end{array}$ \\
\hline $\mathrm{C}$ & -2.82 & 2.49 & -3.25 & 2.50 & -3.53 & 2.66 \\
\hline DI_AWARE & $-0.38 * * *$ & 0.06 & $-0.39 * * *$ & 0.06 & $-0.37 * * *$ & 0.07 \\
\hline Q8_1_STABLE_ER & & & 0.09 & 0.07 & & \\
\hline Q8_1_INCOME & & & $0.18 * * *$ & 0.07 & & \\
\hline Q8_1_DEVELOP_FOR_TRADE & & & $0.62 * * *$ & 0.17 & & \\
\hline Q8_1_DEVELOP_DOM_TRADE & & & 0.09 & 0.09 & & \\
\hline PAY_PREF_SOMONI & & & & & $-0.59 * * *$ & 0.11 \\
\hline PAY_PREF_USD & & & & & $0.51 * * *$ & 0.11 \\
\hline PAY_PREF_EURO & & & & & $0.86 * * *$ & 0.23 \\
\hline PAY_PREF_RUBLES & & & & & $0.44 * * *$ & 0.14 \\
\hline FEMALE & -0.05 & 0.05 & -0.05 & 0.05 & -0.06 & 0.05 \\
\hline LOG(AGE) & 0.51 & 1.38 & 0.64 & 1.39 & 1.32 & 1.47 \\
\hline $\mathrm{LOG}(\mathrm{AGE})^{\wedge} 2$ & -0.07 & 0.19 & -0.09 & 0.19 & -0.19 & 0.20 \\
\hline VILLAGE & $0.16^{* * *}$ & 0.06 & $0.16^{* * *}$ & 0.06 & $0.25 * * *$ & 0.06 \\
\hline MARRIED & 0.02 & 0.06 & 0.04 & 0.06 & 0.00 & 0.07 \\
\hline EDUCATION_HIGHER_PLUS & -0.02 & 0.05 & -0.03 & 0.05 & -0.05 & 0.05 \\
\hline LOG(INCOME) & $0.10 * *$ & 0.04 & $0.11^{* *}$ & 0.04 & 0.04 & 0.05 \\
\hline EMPLOYED & $0.14 * *$ & 0.06 & $0.14 * *$ & 0.06 & $0.12 *$ & 0.07 \\
\hline REMITTANCES-TO-INCOME & $2.41 * * *$ & 0.41 & $2.42 * * *$ & 0.41 & $2.23 * * *$ & 0.43 \\
\hline REGIONAL DUMMIES (23) & Included & & included & & included & \\
\hline McFadden R-squared & 0.31 & & 0.32 & & 0.39 & \\
\hline S.D. dependent var & 0.50 & & 0.50 & & 0.50 & \\
\hline Mean dependent var & 0.45 & & 0.45 & & 0.45 & \\
\hline Log likelihood & $-1,802$ & & $-1,793$ & & $-1,602$ & \\
\hline Obs with Dep $=0$ & 2,100 & & 2,100 & & 2,100 & \\
\hline Obs with Dep $=1$ & 1,717 & & 1,717 & & 1,717 & \\
\hline Total obs & 3,817 & & 3,817 & & 3,817 & \\
\hline
\end{tabular}

Note: $* * *, * *$, and $*$ represent significance at 99,95 , and 90 percent confidence level, respectively.

Table 4 (first regression) reports estimation results using the probability of holding deposits exclusively in foreign exchange as the dependent variable. As before, DI_Aware reduces the likelihood of individuals' keeping the deposits exclusively in FX. Control variables affect deposit dollarization in the same fashion as cash dollarization.

We also tested whether the reasons for holding deposits in general had any implications for the currency mix (Table 4, second regression). As expected, trust in banks reduces the probability that deposits are kept exclusively in forex (that is, reduces liability dollarization). Similarly, the ease of withdrawing deposits from banks reduces the likelihood that deposits 
are kept exclusively in FX. Conversely, interest earning considerations make it more likely for depositors to keep their savings in FX.

Table 4. Probit Regression Results: Deposit Dollarization

(Dependent Variable: Probability of Holding Deposits Exclusively in Foreign Exchange)

\begin{tabular}{|c|c|c|c|c|}
\hline Variable & Coeff. & $\begin{array}{r}\text { Std. } \\
\text { Error }\end{array}$ & Coeff. & $\begin{array}{l}\text { Std. } \\
\text { Error }\end{array}$ \\
\hline $\mathrm{C}$ & $-4.75 *$ & 2.55 & -4.07 & 2.56 \\
\hline DI_AWARE & $-0.27 * * *$ & 0.07 & $-0.25 * * *$ & 0.07 \\
\hline Q9_1_TRUST_BANK & & & $-0.20 * * *$ & 0.07 \\
\hline Q9_1_EARN_INCOME & & & $0.12 *$ & 0.07 \\
\hline Q9_1_EASY_RECEIVE & & & $-0.24 * * *$ & 0.09 \\
\hline Q9_1_EASY_KEEP & & & 0.00 & 0.09 \\
\hline FEMALE & -0.05 & 0.05 & -0.07 & 0.05 \\
\hline LOG(AGE) & 1.77 & 1.41 & 1.48 & 1.42 \\
\hline $\mathrm{LOG}(\mathrm{AGE})^{\wedge} 2$ & -0.25 & 0.19 & -0.21 & 0.19 \\
\hline VILLAGE & -0.08 & 0.09 & -0.09 & 0.09 \\
\hline MARRIED & -0.07 & 0.07 & -0.06 & 0.07 \\
\hline EDUCATION_HIGHER_PLUS & $0.09 *$ & 0.05 & $0.10 *$ & 0.05 \\
\hline LOG(INCOME) & $0.15 * * *$ & 0.05 & $0.15 * * *$ & 0.05 \\
\hline EMPLOYED & $0.13 * *$ & 0.06 & $0.14 * *$ & 0.06 \\
\hline REMITTANCES-TO-INCOME & $1.88 * * *$ & 0.42 & $1.74 * * *$ & 0.42 \\
\hline REGIONAL DUMMIES (23) & included & & Included & \\
\hline McFadden R-squared & 0.32 & & 0.33 & \\
\hline S.D. dependent var & 0.50 & & 0.50 & \\
\hline Mean dependent var & 0.51 & & 0.51 & \\
\hline Log likelihood & $-1,713$ & & $-1,697$ & \\
\hline Obs with Dep $=0$ & 1,775 & & 1,775 & \\
\hline Obs with Dep $=1$ & 1,869 & & 1,869 & \\
\hline Total obs & 3,644 & & 3,644 & \\
\hline
\end{tabular}

Note: $* * *, * *$, and $*$ represent significance at 99,95 , and 90 percent confidence level, respectively.

Perception that FX can be easily withdrawn, if needed, reduces the probability of deposits being held exclusively in FX. To the extent that ease of taking FX deposits out of the bank is a proxy for the ease of taking out of all deposits, this may reduce the transaction cost of frequent withdrawals and encourage consumers to keep more somoni and withdraw them more often to pay for (mostly somoni-denominated) current expenditures.

Finally, Table 5 reports regression results using the probability of borrowing (from banks) exclusively in foreign exchange as the dependent variable. Similar to cash and deposit dollarization, DI awareness reduces the probability of borrowing exclusively in FX. 
Table 5. Probit Regression Results: Loan Dollarization

(Dependent Variable: Probability of Borrowing Exclusively in Foreign Exchange)

\begin{tabular}{lrr}
\multicolumn{1}{c}{ Variable } & Coeff. & $\begin{array}{r}\text { Std. } \\
\text { Error }\end{array}$ \\
\hline \hline C & -0.99 & 2.50 \\
DI_AWARE & $-0.28 * * *$ & 0.07 \\
FEMALE & 0.04 & 0.05 \\
LOG(AGE) & -0.20 & 1.39 \\
LOG(AGE)^2 & 0.04 & 0.19 \\
VILLAGE & 0.01 & 0.06 \\
MARRIED & -0.01 & 0.07 \\
EDUCATION_HIGHER_PLUS & $0.12 * *$ & 0.05 \\
LOG(MFI) & $0.13 * * *$ & 0.05 \\
EMPLOYED & $0.22 * * *$ & 0.06 \\
REMITTANCES-TO-INCOME & $1.65 * * *$ & 0.42 \\
REGIONAL DUMMIES (23) & included & \\
\hline McFadden R-squared & 0.22 & \\
S.D. dependent var & 0.49 & \\
Mean dependent var & 0.42 & \\
Log likelihood & $-1,743.1$ & \\
Obs with Dep=0 & 1,896 & \\
Obs with Dep=1 & 1,392 & \\
Total obs & 3,288 & \\
\hline \hline
\end{tabular}

Note: $* * *, * *$, and $*$ represent significance at 99,95 , and 90 percent confidence level, respectively.

The coefficient estimates on control variables are largely similar to those reported in Tables 3 and 4.

\section{CONCLUSION AND RECOMMENDATIONS}

As hypothesized, the results discussed above offer a strong support for the role of awareness of DI in channeling remittances through the formal financial system and reducing the dollarization of their use. DI awareness is strongly associated with the use of formal channels of transmission of remittances and the dollarization for our sample. In addition, the coefficient estimates on various control variables shed useful light on the mechanists of transfer and use of remittances in Tajikistan. Despite the shortcomings of the sample, most notably associated with some survey design and data collection issues, the results confirm our theoretical priors and are consistent with the very limited research available on the topic.

While somewhat intuitive, (the robustness of) the results offer a relatively inexpensive wayvia improved awareness of existing DI services and capacity - for policymakers to help boost the profitability of the banking sector, improve effectiveness of monetary policy, and reduce financial sector vulnerabilities. Specifically, our results call for public relations' measures and programs to enhance awareness of DI and the benefits it offers. While bank and MFO 
branches should be the main windows where DI-related publications would be disseminated, the DIF could seek to use public and social media outlets to spread the word more widely in a cost-effective fashion. More traditional outreach tools, such as dissemination of DIF's Annual Reports (and related press releases) and maintaining toll-free phone lines (where public can reach DIF staff for questions) could be productive depending on the specifics of the area/region. ${ }^{21}$ IADI (2009) provides useful guidance in this regard.

Related to this is the need to expand the coverage of DI protection and enhance DIF's operational/payout capabilities, as suggested by joint WB-IMF financial sector assessment (WB-IMF, 2015), that is, to make the DI coverage more meaningful and credible. Additional recommendations in this regard may also include: (1) developing banking products and services aimed at remitters and their families; ${ }^{22}(2)$ enhancing competition among service providers; ${ }^{23}$ (3) introducing/improving payment infrastructure (e.g., payment card systems and other innovative payment mechanisms), ${ }^{24}$ and (4) extending the geographic coverage of services. ${ }^{25}$

Finally, while data limitations prevented us from testing/measuring the impact of this in the current paper, we hypothesize that improving the health of, and the trust in, the banking sector will act as implicit insurance and entice the remittance senders and receivers to use the formal channels more frequently. This will in turn contribute to deepening the banking sector and increasing population's access to financial services, thus feeding back into the strength of the sector. Unfortunately, the health of the financial sector in Tajikistan has deteriorated since the survey was conducted. Remittances and associated deposit balances have dropped significantly since the start of the crisis in Russia in December 2014, bringing some large Tajik banks to the brink of collapse and resulting in further tightening of regulations, including those related to FX transactions. This is likely to change the relations between variables described in our paper and require some caution in extending the findings to the present day.

\footnotetext{
${ }^{21}$ These measures could be undertaken within the overall effort to improve general financial literacy. Behavioral economics and psychology as well as latest empirical research in development finance could provide useful insights into the financial behavior of consumers, which can improve the effectiveness of financial literacy programs.

${ }^{22}$ Giving account access to both senders abroad and their families at home and offering mobile remittance solutions could be steps in this direction.

${ }^{23}$ Different types of entities should be permitted to provide remittance services and the requirements applicable to them are proportionate to the specific risks associated with the service.

${ }^{24}$ This will help reduce the transaction cost associated with transfer and disbursement of remittances

${ }^{25}$ Allowing for different types of entities (such as, MFOs, the postal operator, and other non-bank providers) to participate in the remittance market may help extend the coverage of remittance distribution networks, including in rural areas. A more widespread and cost-efficient coverage of rural areas can be achieved through agent-based models.
} 


\section{REFERENCES}

Abenoja , Zeno Ronald, 2004. Promoting Greater Use of Formal Remittance Systems by Overseas Filipinos.” Mimeo, Financial Market Research Group, Department of Economic Research, Central Bank of the Philippines. Available via link.

Aggarwal, Reena, Asli Demirgüç-Kunt, and Maria Soledad Martínez Pería, 2011. "Do Remittances Promote Financial Development?" Journal of Development Economics, 96(2), November, pp. 255-64.

Anginer, Deniz, Asli Demirgüç-Kunt, and Min Zhu, 2013. "How Does Deposit Insurance Affect Bank Risk? Evidence from the Recent Crisis," Journal of Banking and Finance.

Barajas, Adolfo, and R. Armando Morales. 2003. "Dollarization of Liabilities: Beyond the Usual Suspects," IMF Working Paper 03/11, International Monetary Fund, Washington, D.C.

Bank for International Settlements, 2009. "Core Principles for Effective Deposit Insurance Systems," Basel Committee on Banking Supervision and International Association of Deposit Insurers. Available via: http://www.bis.org/publ/bcbs156.pdf

Bartiloro, Laura, 2011. "Is Your Money Safe? What Italians Know About Deposit Insurance," Financial Institutions Center, Wharton School, Univ. of Pennsylvania. Available via: http://fic.wharton.upenn.edu/fic/papers/11/11-55.pdf

Bijlsma, M and K. van der Wiel, 2012. "Consumer perception of deposit insurance: Little awareness, limited effectiveness?" Available via link.

Billmeier, Andreas and Johan Mathisen, 2006. "Analyzing Balance-Sheet Vulnerabilities in a Dollarized Economy: The Case of Georgia," IMF Working Paper 06/173. International Monetary Fund, Washington, DC. Available via link.

Broda, Christian and Eduardo Levy Yeyati, 2003. "Endogenous Deposit Dollarization," Federal Reserve Bank of New York Staff Report No. 160. Available via link.

Brown, Martin and Helmut Stix, 2014. "The Euroization of Bank Deposits in Eastern Europe," Working Paper 197, Oesterreichische Nationalbank (Austrian Central Bank).

Grigorian, David and Vlad Manole, 2016. "Sovereign Risk and Deposit Dynamics: Evidence from Europe," Applied Economics (December). Available via link.

Grigorian, David and Tigran A. Melkonyan, 2011. "Destined to Receive: The Impact of Remittances on Household Decisions in Armenia," Review of Development Economics, 15(1), pp. 139-53. 
Hernandez-Coss, Raul, 2005. "A Proposed Framework to Analyze Informal Funds Transfer Systems," in "Remittances: Development Impact and Future Prospects," Samuel Munzele Maimbo and Dilip Rathe (eds.), The World Bank, Washington, DC.

Inakura, Noriko, Satoshi Shimizutani and Ralph Paprzycki, 2005. "Deposit Insurance and Depositor Discipline: Direct Evidence on Bank Switching Behavior in Japan," Institute of Economic Research, Hitotsubashi University, Discussion Paper Series No. 125. Available via: https://ideas.repec.org/p/hst/hstdps/d05-125.html

Inter-American Development Bank, 2004 "Unlocking Credit: The Quest for Deep and Stable Bank Lending.” Available via link.

International Association of Deposit Insurers, 2009. "Public Awareness of Deposit Insurance Systems." Available via link.

International Monetary Fund, 2016. "Republic of Tajikistan: Financial System Stability Assessment," Washington, DC. Available via link.

Kireyev, Alexei, 2006. "The Macroeconomics of Remittances: The Case of Tajikistan," IMF Working Paper No. 06/2.

Kose, Anneke and Robert Vermeulen, 2014. "Migrants' Choice of Remittance Channel: Do General Payment Habits Play a Role?” European Central Bank Working Paper No. 1683, June. Available via link.

Luca, Alina, and Iva Petrova, 2003, "Credit Dollarization in Transition Economies: Is It Firms' or Banks' "Fault"?”, mimeo, Michigan State University. Available via link.

Lusardi, Annamaria. 2008, "Household Saving Behavior: The Role of Financial Literacy, Information, and Financial Education Programs", mimeo, Dartmouth College. Available via link.

Narazani, Edlira, 2013, "A Micro Level Perspective of Euroization in Albania”, The WIIW Balkan Observatory Working Paper No. 109. Available via link.

Rivers, D., and Q. H. Vuong, 1988, “'Limited Information Estimators and Exogeneity Tests for Simultaneous Probit Models,' Journal of Econometrics, vol. 39, pp. 347-66

Siegel, Melissa and Matthias Lücke, 2009. "What Determines the Choice of Transfer Channel for Migrant Remittances? The Case of Moldova," Kiel Working Paper No. 1515, April. Available via: https://www.files.ethz.ch/isn/100017/kwp_1515.pdf.

Strater, Norbert, Markus Cornelissen, and Andreas Pfingsten, 2008. "Deposit Insurance: An Empirical Study of Private Investors' Knowledge and Perception,” mimeo, University of Munster. Available via link.

Stix, H., 2010. "Euroization: What Factors Drive its Persistence? Household Data Evidence for Croatia, Slovenia and Slovakia," Applied Economics, vol. 42, pp. 1-16 
Suki, Lenora, 2004. "Financial Institutions and the Remittances Market in the Dominican Republic," Center on Globalization and Sustainable Development, The Earth Institute at Columbia University, New York, NY. Available via link.

World Bank and International Monetary Fund, 2015. "Financial Sector Assessment: Republic of Tajikistan." Available via link. 


\title{
APPENDIX I. QUESTIONNAIRE Form: SURVEY ON ASSESSMENT OF FoREIGN CURRENCY CirCULATION IN THE REPUBLIC OF TAJIKISTAN
}

\author{
National Bank of Tajikistan \\ Questionnaire
}
Survey on assessment of foreign currency circulation in the Republic of Tajikistan Conducted: September 22 - October 16, 2014

1. General information on respondent:

\begin{tabular}{lllll} 
1.1. & 1.2. Age: & 1.3. Place of living: & \multicolumn{2}{l}{ 1.4. Marital status: } \\
Gender: & $16-25 \square 26-35 \square 36-45 \square$ & city & married & $\square$ \\
Male & $46-55 \square 56-65 \square 66-75 \square$ & small town & $\square$ & single \\
& 76 and older $\square$ & village & $\square$ & divorced
\end{tabular}

Female

\subsection{Family members:}

Person, who was surveyed the first husband $\square$ brother $\square$ father $\square$ son $\square$ son-in-law

relatives $\square$ wife $\square$ sister $\square$ mother daughter $\square$ daughter-in-law another person

Total family members (people)

\subsection{Employment:}

$\square$ civil service public services

$\square$ economy and finances

$\square$ agriculture

$\square$ trade

$\square$ transport

\subsection{Occupation:}

code:

$\square \square$ other

\subsection{Education:}

Higher $\square$ Ugrad $\square$ vocational secondary $\square$ elementary vocational $\square$ secondary other (write) do not know

\subsection{Position/post:}

$\square$ Employee $\quad \square$ retired $\square$ Entrepreneur $\square$ other

$\square$ Lessee (write) (write)

(write)

2. What is the monthly income of your family (in TJS)?

from 100 to $1000 \square$ from 1000 to $2000 \square$ from 2000 to $3000 \square$ from 3000 to $4000 \square$ from 4000 and more $\square$

\section{What percentage of your family's total monthly income represent remittances received from abroad? \\ up to $10 \% \square$ from 10 to $20 \% \square$ from 20 to $30 \% \square$ from $30 \% \square$ more}

4. What are the sources of money, which represent your family's income from abroad? 


\begin{tabular}{l}
\hline pension $\square \quad$ help of friends $\square \quad$ other $\square$ \\
\hline 5. Remittances, which you receive from abroad are mainly from what country? \\
Russia $\square \quad$ Kazakhstan $\square \quad$ Belarus $\square \quad$ Other $\square$ \\
\hline 6. How do you receive remittances from abroad? \\
through banks $\square \quad$ through company(organization) $\square \quad$ through individuals $\square$ other way $\square$ \\
\hline 7. How do you spend remittances in forex? \\
For food and household services $\square \quad$ to purchase property $\square \quad$ to purchase a car $\square$ \\
For wedding or other ceremonies $\square \quad$ for business $\square \quad$ for savings $\square \quad$ to purchase gold $\square$ \\
to purchase shares (other securities) $\square$ other $\square$
\end{tabular}

8. In what currency do you prefer to have cash?

TJS $\square \quad$ USD $\square \quad$ Euro $\square \quad$ RUR $\square$ other currency

8.1. What is the reason for having your money in forex?

More stable exchange rate $\square$ is a source of income $\square$ to develop foreign trade $\square$

To develop internal trade $\square$ other $\square$

\section{In what currency do you prefer to have deposits?}

TJS $\square \quad$ USD $\square \quad$ Euro $\square \quad$ RUR $\square \quad$ other currency $\square$

9.1. What is the reason for depositing your money in forex in the bank?

Trust in bank $\square \quad$ for income $\square \quad$ easy to receive $\square \quad$ easy to keep $\square \quad$ other $\square$

10. Do you know that the banks that function in Tajikistan provide guarantees for savings of customers?
1) yes
2) no

11. In what form (cash or noncash) do you keep your money?

USD cash $\square \quad$ savings in USD $\square$ other forex cash $\square \quad$ jewelry $\square \quad$ gold $\square \quad$ silver $\square$ TJS cash $\square \quad$ savings in TJS $\square \quad$ real estate $\square \quad$ other $\square$

12. In your opinion, what prevents you to keep your money in the banks?

Lack of trust in banks $\square \quad$ Lack of free financial resources $\square$

Low interest rate $\square \quad$ other

13. Did your family borrow from the banks of Tajikistan (for example, credit for purchase):

Yes $\square$ No $\square$

14. In which currency do you prefer to borrow?

USD $\square$ Euro $\square-$ RUR $\square$

TJS $\square$ USD $\square \quad$ Euro $\square$

TJS $\square \quad$ USD $\square \quad$ Euro $\square \quad$ RUR $\square \quad$ other $\square$

16. The share of forex cash that you had in the last few years:
1) increased
2) decreased
3) did not change

17. Which currency do you prefer in future to improve your living standards?:

TJS $\square \quad$ USD $\square \quad$ Euro $\square \quad$ RUR $\square \quad$ other $\square$

